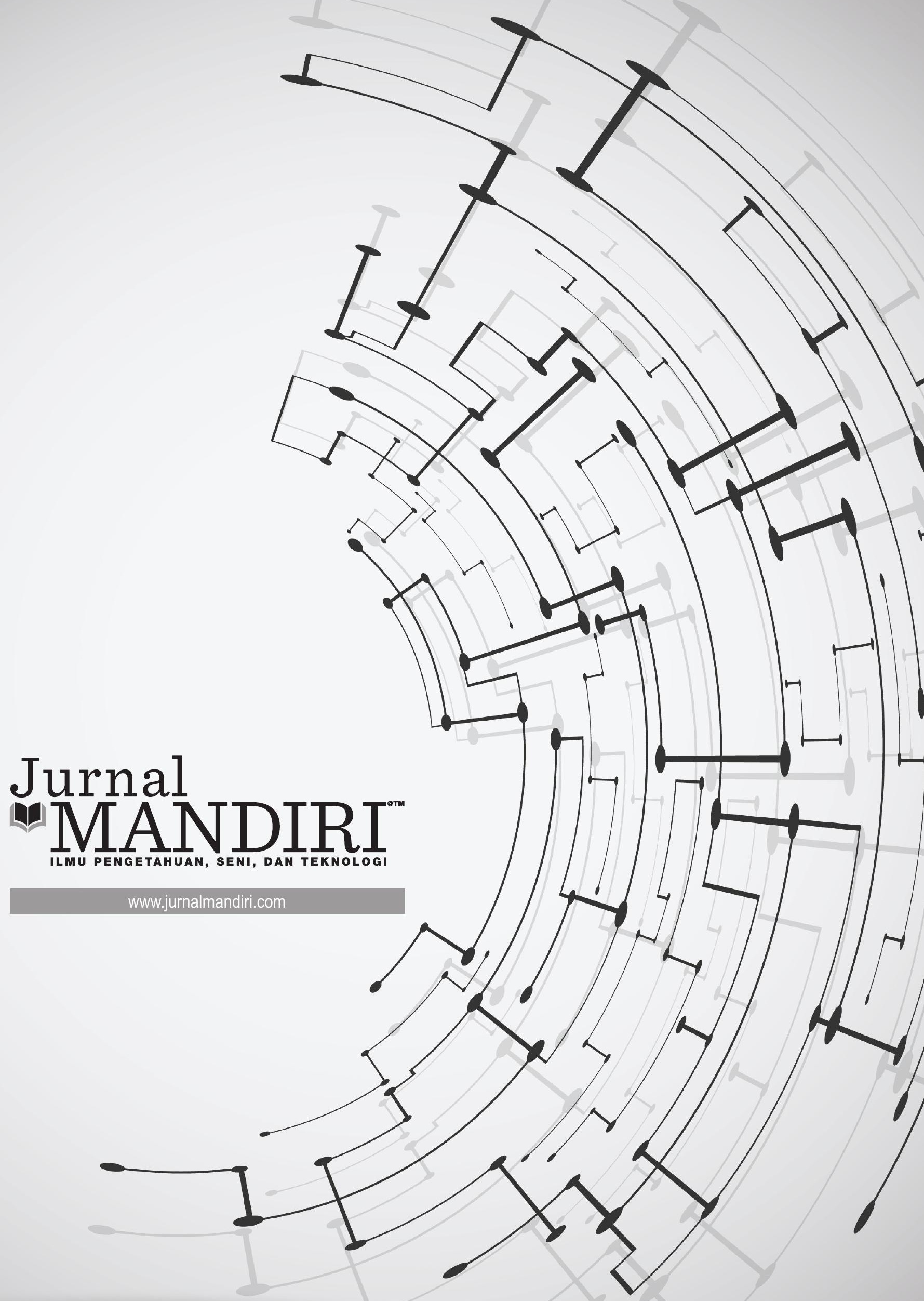


ISSN : 2580-3220, E-ISSN : 2580-4588

J. Mandiri., Vol. 4, No. 1, Juni 2020 (105 - 113)

C2018 Lembaga Kajian Demokrasi

dan Pemberdayaan Masyarakat (LKD-PM)

DOI : https://doi.org/10.33753/mandiri.v4i1.110

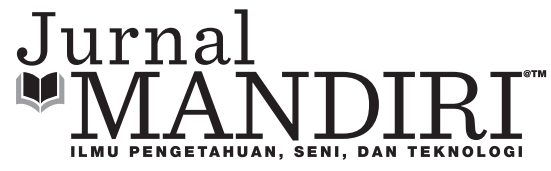

\title{
Kelayakan Bisnis Café "Kopdar" di Tangerang Selatan Dari Aspek Kriteria Penilaian Investasi
}

\author{
Syamruddin \\ Fakultas Ekonomi, Universitas Pamulang \\ dosen01343@unpam.ac.id
}

\begin{abstract}
Abstrak
Tujuan penelitian ini untuk menganalisis kelayakan usaha café "Kopdar" yang ada di Tangerang Selatan. Adapun fokus analisis kelayakan usaha adalah pada aspek keuangan atau finansial. Penelitian ini bersifat deskriptif kuantitatif. Jenis data yang digunakan adalah data primer. Sedangkan metode yang digunakan adalah dengan cara analisis finansial yang meliputi Payback Period (PP), Net Present Value (NVP), dan Internal Rate of Return (IRR). Berdasarkan hasil dan pembahasan, diketahui dari ketiga metode analisis finansial yang digunakan di atas dapat disimpulkan bahwa investasi bisnis café yang ada di Tangerang Selatan dari aspek finansial layak dan dapat diterima serta dilanjutkan. Dari hasil penelitian menunjukkan bahwa PP adalah 6,149 bulan, atau lebih singkat dari PP yang ada di daerah penelitian yaitu berkisar antara 9 sampai 24 bulan. Sementara itu NPV sebesar Rp7,792,518.52 di mana hasil dari nilai NPV ini menunjukkan hasil yang positif. Sedangkan IRR sebesar 12,284 \%, lebih tinggi dari nilai return yang berlaku di pasar (discount factor) saat ini yaitu sekitar $6,50 \%$.
\end{abstract}

Kata Kunci : Analisis Kelayakan, Aspek Finansial, PP, NPV, IRR

\begin{abstract}
The purpose of this study is to analyze the feasibility of "Kopdar" café business in South Tangerang. The focus of the business feasibility analysis is on the financial or financial aspects. This research is quantitative descriptive. The type of data used is primary data. While the method used is by means of financial analysis which includes Payback Period (PP), Net Present Value (NVP), and Internal Rate of Return (IRR). Based on the results and discussion, it is known from the three methods of financial analysis used above that it can be concluded that the investment in the café business in South Tangerang is financially feasible and can be accepted and continued. The results showed that $P P$ is 6,149 months, or shorter than $P P$ in the study area, which ranged from 9 to 24 months. Meanwhile NPV of Rp7,792,518.52 where the results of this NPV value show positive results. While IRR of $12.284 \%$, higher than the return value prevailing in the market (discount factor) which is currently around $6.50 \%$.
\end{abstract}

Keywords : Feasibility Analysis, Financial Aspect, PP, NPV, IRR

\section{PENDAHULUAN}

Bisnis kuliner adalah bisnis tentang rasa. Sejatinya, bagaimana para chef atau pengelola di dunia bisnis ini mampu meracik dan mengolah makanan atau minuman sedemikian rupa, sehingga terasa enak di lidah. Pada gilirannya, akan membuat orang atau konsumen agar tertarik untuk datang guna mencicipi hidangan yang disajikan, semata-mata demi untuk memanjakan lidahnya. Bahkan, ada pula yang datang, walaupun 
hanya sekadar untuk melihat dan menikmati bagaimana cara menyajikan hidangan yang lezat dan enak serta tampak indah di pandang mata.

Belakangan ini bisnis kuliner sudah masuk ke area industri. Kuliner tidak hanya sekadar bagaimana membuat dan menyajikan minuman dan makanan, namun juga sudah menjadi bisnis yang menarik minat cukup besar dan luar biasa di masyarakat. Bahkan, mampu menyedot modal yang sangat besar dengan jumlah tenaga kerja yang sangat banyak sehingga membuat perputaran uang atau modal pada bisnis kuliner ini juga menjadi begitu besar.

Salah satu bisnis kuliner yang sangat menjanjikan saat ini adalah café atau kedai-kedai/warung-warung kopi. Bak jamur di musim hujan, café-café tumbuh dan berkembang begitu pesat di mana-mana. Tidak hanya di perkotaan, namun juga di berbagai pelosok daerah di Tanah Air. Café tidak hanya sekadar menyajikan minuman dan makanan, namun juga sudah menjadi sebuah seni kulinari (culinary arts), yang di dalamnya menyajikan berbagai jasa dan produk yang dapat memanjakan para pengunjungnya/pelanggan.

Culinary Arts adalah sebuah seni menyiapkan sebuah makanan dengan berbagai kreatifitas dari chef itu sendiri. Seorang chef berbakat di bidang culinary arts adalah mereka yang memiliki rasa ingin tahu yang besar dan berani mencoba sebuah hal baru selain memiliki kecintaan terhadap dunia kuliner.

Di Tangerang Selatan, bisnis café juga tak luput dari perhatian para pemodal atau investor. Sehingga tak heran apabila café banyak bermunculan di berbagai pelosok di setiap sudut kota. Tidak hanya di pinggir-pinggir jalan protokol ataupun jalan-jalan besar lainnya, namun juga sudah masuk ke jalan-jalan kecil, bahkan ganggang hingga komplek-komplek perumahan.

Café-café dengan skala kecil yang umumnya merupakan warung-warung kopi yang lebih dikenal dengan istilah "Kopdar", dewasa ini sangat banyak sekali bermunculan. Apalagi investasi yang ditanamkan untuk café seperti ini tidaklah besar dan cukup dengan modal kecil hingga sedang. Dalam kurun waktu sepuluhan tahun belakangan ini, Tangerang Selatan memang dihiasi oleh kedai-kedai kopi yang lebih akrab disebut masyarakat sebagai café. Tidak hanya yang ada di mall-mall dan pusat perbelanjaan, namun juga sudah merambah ke seluruh seantero kota.

Besarnya animo masyarakat dalam berbisnis café di Tangerang Selatan membuat persaingan bisnis juga tak terelakkan. Akibatnya, para pebisnis café harus benar-benar mampu memberikan pelayanan yang baik dan maksimal serta menjanjikan bagi pengunjung café-nya. Dengan harapan café-nya tidak pernah sepi dari pengunjung. Selain itu harus bisa pula mengelola bisnisnya dari berbagai aspek kelayakan bisnis. Oleh karena itu perlu dilakukan studi kelayakan sebelum investor memutuskan untuk membuka bisnis café-nya.

Menurut Umar (2015), studi kelayakan adalah sebuah penelitian terhadap rencana bisnis yang tidak hanya melakukan layak atau tidaknya suatu bisnis untuk dibangun. Akan tetapi juga saat dioperasionalkan secara kontinu dalam mencapai keuntungan yang maksimal dengan waktu yang telah ditentukan.

Selain itu, studi kelayakan juga dapat didefinisikan sebagai sebuah studi yang digunakan untuk menilai layak atau tidaknya sebuah usaha dilakukan dengan pertimbangan mendapatkan keuntungan. Studi kelayakan adalah penelitian tentang dapat tidaknya suatu proyek investasi dilaksanakan dengan berhasil (Jumingan, 2011).

Sedangkan menurut Purnomo, Riawan, dan Sugianto, (2017), dalam bukunya yang berjudul : "Studi Kelayakan Bisnis", dijelaskan bahwa studi kelayakan sering disebut sebagai suatu bahan pertimbangan untuk mengambil keputusan, apakah gagasan usaha atau proyek yang direncanakan tersebut dapat diterima atau justru harus ditolak. Layak yang dimaksud adalah apakah gagasan tersebut memberikan manfaat yang baik dari segi finansial maupun dari segi sosial.

Oleh karena itu sudah barang tentu bisnis café juga tidak hanya sekadar memberikan layanan yang dapat memuaskan para pengunjung dan pelanggannya. Bisnis café juga harus dikelola secara profesional, melalui studi kelayakan yang salah satunya adalah dari aspek keuangan/finansial. Karena biar bagaimanapun juga aspek 
finansial akan menjadi salah satu tolok ukur bagi keberhasilan suatu bisnis.

Dalam menjalankan sebuah usaha (bisnis), keberhasilannya ditentukan oleh bagaimana para pelakunya mengelola usaha tersebut. Adapun pengelolaan suatu usaha atau bisnis meliputi berbagai aspek seperti aspek pasar dan pemasaran, aspek keuangan, aspek operasi, aspek sumber daya manusia, aspek organisasional, aspek hukum serta aspek lingkungan (Kasmir \& Jakfar, 2017).

Selanjutnya, dalam penelitian ini tidak semua aspek tersebut di atas akan dianalisis. Sebab berdasarkan wawancara dengan pengelola café yang ada di lokasi yang diteliti, pada umumnya mereka lebih fokus pada aspek keuangan dan aspek pasar/ pemasaran (lokasi dan potensi pasar). Karena kedua aspek inilah yang menjadi pertimbangan mereka sebelum memutuskan untuk membuka café di suatu lokasi atau wilayah.

Namun, secara khusus pula dalam penelitian ini, penulis hanya memfokuskan pada pembahasan tentang aspek keuangan/finansial. Dalam hal ini aspek keuangan berfokus pada analisis sumber pembiayaan dan memprediksi arus kas pada masa yang akan datang. Pada gilirannya akan berujung pada tingkat keuntungan yang layak.

Kendati usaha café tidak tergolong sebagai usaha yang membutuhkan modal yang besar, namun bagaimanapun juga setiap investasi pasti mengandung risiko kegagalan. Tentunya, tidak ada satupun pemodal atau pebisnis yang ingin gagal. Setiap pebisnis pastilah ingin sukses dalam menjalankan bisnisnya sehingga mampu meraup keuntungan yang besar, terutama secara finansial.

Dengan demikian, kecil atau besarnya suatu investasi maka harus dikelola dengan benar dan professional. Investasi dapat didefinisikan sebagai komitmen atas sejumlah dana maupun sumber lain yang dilakukan pada saat ini, dengan tujuan untuk mendapatkan keuntungan di masa datang (Tandelilin, 2010).

Selain pengelolaan investasi yang baik, manajemen cash flow juga harus menjadi pertimbangan dalam menjalankan bisnis. Karena dengan pengelolaan cash flow yang baik, akan menunjukkan suatu bisnis dikelola dengan benar atau tidak. Aliran kas (cash flow) merupakan aliran kas yang ada di perusahaan dalam periode tertentu. Cash flow menunjukkan berapa uang yang masuk ke perusahaan serta jenis-jenis pemasukan tersebut. Cash flow juga menggambarkan berapa uang yang keluar serta jenis-jenis biaya yang dikeluarkan (Sucipto, 2011).

Oleh karena itu, manfaat adanya analisis kelayakan usaha ini, selain untuk meminimalisir kerugian, juga bermanfaat dalam memudahkan perencanaan dan pengendalian usaha yang akan dilaksanakan. Dengan demikian sudah selayaknya setiap calon pemodal atau pebisnis mengetahui kelayakan tiap-tiap aspek tersebut agar tujuan investasinya tidak gagal.

Pada umumnya alat ukur yang digunakan untuk menentukan kelayakan suatu usaha dari aspek keuangan/finansial atau berdasarkan kriteria investasi dapat dilakukan melalui pendekatan metode penilaian investasi. Adapun yang umum digunakan antara lain :

- Payback Period (PP)

- Average Rate of Return (ARR)

- $\quad$ Net Present Value (NPV)

- Internal Rate of Return (IRR)

- Profitability Index (PI)

- Break Event Point (BEP)

Namun, dalam penelitian ini penulis hanya mengambil tiga pendekatan metode kriteria penilaian investasi. Ketiga metode tersebut adalah PP, NPV, dan IRR. Dalam pembahasannya, ketiga metode tersebut akan menjadi alat atau pisau analisis untuk mengetahui layak atau tidaknya investasi yang ditanamkan.

Kriteria penilaian investasi merupakan alat ukur yang digunakan untuk menentukan apakah suatu proyek layak untuk dilaksanakan atau tidak layak untuk dilaksanakan. Selanjutnya menurut Dedi Purwana E.S. \& Nurdin Hidayat (2017), kelayakan investasi dapat dilihat dari layak tidaknya suatu investasi ditinjau dari aspek keuangan. Analisis yang digunakan dalam penilaian kelayakan investasi adalah dengan cara membandingkan hasil analisis kelayakan dengan rata-rata industri atau target yang telah ditentukan. Indikator penilaian kelayakan investasi dapat diukur dengan beberapa rasio keuangan.

Dalam praktiknya ada beberapa kriteria 
untuk menentukan apakah suatu usaha layak atau tidak untuk dijalankan ditinjau dari aspek keuangan. Kriteria ini sangat tergantung dari kebutuhan masing-masing perusahaan dan metode yang akan digunakan. Setiap metode yang digunakan memiliki kelebihan dan kelemahannya masing-masing. Dalam penilaian suatu usaha, penilai harus menggunakan beberapa metode. Semakin banyak metode yang digunakan, semakin memberikan gambaran yang lengkap. Dengan demikian, hasil yang diperoleh diharapkan menjadi lebih sempurna.

Suatu bisnis dapat dikatakan layak apabila jenis usaha tersebut mampu memberikan laba usaha yang memadai kepada pihak investor atau pengusaha yang menjalankan usaha. Beberapa kriteria yang biasa digunakan untuk menentukan kelayakan suatu usaha atau investasi secara umum adalah : (1) Payback Period (PP), (2) Average Rate of Return (ARR), (3) Net Present Value (NPV), (4) Internal Rate of Return (IRR), (5) Profitability Index (PI), dan (6) Rasio keuangan seperti rasio Likuiditas, Solvabilitas, Aktivitas, dan Profitabilitas.

Sedangkan kriteria penilaian investasi dalam pandangan Kasmir \& Jakfar (2017), yaitu di mana dalam analisis proyek ada beberapa kriteria yang sering dipakai untuk menentukan diterima atau tidaknya suatu usulan proyek, atau untuk menentukan pilihan antara berbagai macam usulan proyek. Dalam semua kriteria itu, baik manfaat (benefit) ataupun biaya dinyatakan dalam nilai sekarang (present value). Beberapa kriteria tersebut adalah diantaranya yaitu Payback Period (PP), Net Present Value (NPV), dan Internal Rate of Return (IRR).

Selanjutnya berdasarkan penelitian terdahulu yang dilakukan oleh I Gusti Agung Didit Eka Permadi, yang berjudul : Analisis Investasi Penambahan Aktiva Tetap (Mesin Oven) pada UD. Warna Sari di Desa Suranadi, Kecamatan Narmada, Kabupaten Lombok Barat. Adapun penelitian dilakukan pada tahun 2019. Hasil penelitian menunjukkan bahwa Payback Period (PP) adalah 0,09 tahun $<1$ tahun. Artinya investasi layak diterima untuk dilanjutkan.

Kemudian berdasarkan penelitian terdahulu yang dilakukan oleh Prestilia Windy Pratiwi, Titi Rapini, dan Umi Farida, yang berjudul : Analisis Kelayakan Pendirian Usaha Roti Canai di Jalan Baru Ponorogo. Adapun penelitian dilakukan pada tahun 2019. Dari hasil penelitian tersebut diperoleh Net Present Value (NPV) adalah sebesar Rp39,703,244.62 yaitu bernilai positif, yang artinya investasi ini menguntungkan. Hal ini berarti investasi layak diterima untuk dilanjutkan.

Sedangkan berdasarkan penelitian terdahulu yang dilakukan oleh Nabila Ananda Putri, Zumi Saidah, Dika Supyandi, dan Lucyana Trimo, yang berjudul : Analisis Kelayakan Bisnis Kedai Kopi (Studi Kasus Pada Agrowisata N8 Malabar, Pangalengan, Kabupaten Bandung). Adapun penelitian dilakukan pada bulan Januari sampai Juli 2019. Sesuai dengan penelitian maka telah didapatkan hasil perhitungan Internal Rate of Return (IRR) sebesar 49,51 \%. Persentase ini lebih besar dari indikator kelayakan yaitu sebesar $18 \%$. Dengan demikian investasi layak diterima untuk dilanjutkan.

Oleh karena itu berdasarkan hal-hal di atas, maka penulis tertarik untuk melakukan penelitian dengan mengambil judul : "Kelayakan Bisnis Café "Kopdar" di Tangerang Selatan Dari Aspek Kriteria Penilaian Investasi."

\section{METODE}

Penelitian ini merupakan penelitian yang bersifat deskriptif kuantitatif. Metode penelitian kuantitatif, menurut Sugiyono (2012) adalah metode penelitian yang berlandaskan pada filsafat positivisme, digunakan untuk meneliti pada populasi atau sampel tertentu, pengumpulan data menggunakan instrumen penelitian, dan analisis data bersifat kuantitatif/statistik, dengan tujuan untuk menguji hipotesis yang telah ditetapkan. Sedangkan penelitian deskriptif yaitu penelitian yang dilakukan untuk mengetahui nilai variabel mandiri, baik satu variabel atau lebih (independen) tanpa membuat perbandingan, atau menghubungkan dengan variabel yang lain. Berdasarkan teori tersebut, penelitian deskriptif kuantitatif merupakan data yang diperoleh dari sampel populasi penelitian dianalisis sesuai 
dengan metode statistik yang digunakan.

Selanjutnya, adapun jenis data yang digunakan adalah data primer. Sementara itu lokasi penelitian yaitu café yang ada di Tangerang Selatan. Penelitian dan pengambilan data dilaksanakan pada bulan Januari sampai Maret 2020. Adapun sampel penelitian adalah salah satu café yang ada di Pamulang, Kemudian dalam penelitian ini dilakukan analisis finansial dengan menggunakan Metode PP, NPV, dan IRR.

Payback Period (PP) adalah jangka waktu tertentu yang menunjukkan terjadinya arus penerimaan (cash inflows) secara kumulatif sama dengan jumlah investasi dalam bentuk present value. Payback Period mengukur seberapa cepat suatu investasi kembali Sucipto (2011).

Sementara itu menurut Wijayanto (2012), payback period merupakan periode yang diperlukan untuk menutup kembali pengeluaran investasi. Jika periode payback lebih pendek dari yang disyaratkan, maka suatu proyek tersebut dikatakan menguntungkan, begitu juga sebaliknya.

Secara singkat, formula untuk menghitung Payback Period yaitu :

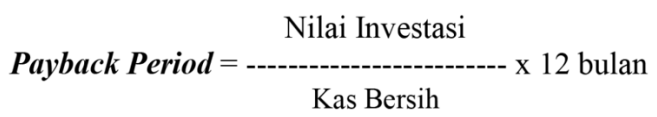

Selanjutnya NPV atau nilai sekarang bersih adalah analisis manfaat finansial yang digunakan untuk mengukur layak tidaknya suatu usaha untuk dilaksanakan jika dilihat dari nilai sekarang (present value) arus kas bersih yang akan diterima dibandingkan dengan nilai sekarang dari jumlah investasi yang dikeluarkan.

Menurut Sartono (2010), NPV merupakan selisih antara present value aliran kas bersih dengan present value investasi. Metode ini biasanya digunakan untuk alokasi modal untuk menganalisa keuntungan dalam sebuah proyek yang akan dilaksanakan.

Adapun rumus untuk menghitung NPV adalah :

$$
N P V=-C_{0}+\frac{C_{1}}{(1+i)}+\frac{C_{2}}{(1+i)^{2}}+\ldots+\frac{C_{n}}{(1+i)^{n}}
$$

di mana :

$\mathrm{Co}=$ Initial Investment (Biaya Investasi Awal)
$\mathrm{C} 1$ = Arus Kas Investasi pada Tahun Pertama

$\mathrm{Cn}=$ Arus Kas Investasi pada Tahun ke-n

$\mathrm{i}=$ Tingkat Suku Bunga (Discount Factor)

Kemudian Internal Rate of Return (IRR) atau tingkat pengembalian internal merupakan alat analisis untuk menentukan tingkat pengembalian investasi apakah mempunyai kelebihan dan kekurangan. IRR pada dasarnya merupakan metode untuk menghitung tingkat bunga yang dapat menyamakan antara present value dari semua aliran kas masuk dengan aliran kas keluar dari suatu investasi proyek. Maka, pada prinsipnya metode ini digunakan untuk menghitung besarnya rate of return yang sebenarnya. Pada dasarnya IRR harus dicari dengan trial and error.

Menurut Suliyanto (2010), kriteria kelayakan penerimaan investasi menggunakan metode IRR adalah suatu investasi yang diusulkan dinyatakan layak jika IRR lebih besar dari tingkat keuntungan yang dikehendaki. Sebaliknya, jika IRR suatu investasi lebih kecil dari tingkat keuntungan yang dikehendaki maka investasi tersebut dinyatakan tidak layak. Apabila terdapat beberapa alternatif investasi maka pilih alternatif investasi terbaik dengan memilih alternatif investasi yang mempunyai IRR yang paling besar.

Adapun perhitungan IRR ditempuh melalui metode interpolasi. Sedangkan rumus perhitungan IRR dengan cara interpolasi adalah sebagai berikut :

$$
I R R=i_{1}+\frac{N P V_{1}}{\left(N P V_{1}-N P V_{2}\right)}\left(i_{2}-i_{1}\right)
$$

Adapun indikator IRR adalah sebagai berikut:

- Apabila IRR > DF (Discount Factor) yang berlaku, maka proyek layak untuk dilaksanakan/dilanjutkan.

- Apabila IRR < DF (Discount Factor) yang berlaku, maka proyek tidak layak untuk dilaksanakan/dilanjutkan.

\section{HASIL dan PEMBAHASAN Hasil}

Analisis aspek finansial merujuk pada tingkat kelayakan usaha yang dilihat dari aspek keuangan. 
Adapun berikut ini merupakan data-data finansial (perkiraan) yang diperoleh dari hasil wawancara.

\begin{tabular}{|c|c|c|}
\hline \multicolumn{3}{|c|}{ Tabel 1. Data-Data Finansial } \\
\hline Modal Awal & Perkiraan & Rujukan \\
\hline Sewa Tempat (1 Tahun) & $10.000 .000-20.000 .000$ & $15,000,000,00$ \\
\hline Kursi dan Meja & $6.500 .000-10.500 .000$ & $8,500,000.00$ \\
\hline Peralatan Masak & $3.500 .000-6.000 .000$ & $5,000,000.00$ \\
\hline Peralatan Makan & $4.000 .000-5.000 .000$ & $3,000,000.00$ \\
\hline \multirow[t]{2}{*}{ Biaya Operasional Awal } & 5.500 .000 & $5,500,000.00$ \\
\hline & & $37,000,000.00$ \\
\hline Biaya Operasional (/bulan) & Perkiraan & Rujukan \\
\hline Gaji Karyawan (3 org) & $7.000 .000-10.000 .000$ & $8,320,000.00$ \\
\hline Listrik dan Air & $500.000-750.000$ & $700,000.00$ \\
\hline Cup, Plastik, dan sejenisnya & $400.000-600.000$ & $500,000.00$ \\
\hline \multirow[t]{2}{*}{ Saus, Kecap, Gula, dan lain-lain } & $350.000-550.000$ & $400,000.00$ \\
\hline & & $9,920,000.00$ \\
\hline Pengeluaran (/hari) & Perkiraan & Rujukan \\
\hline Bahan Pokok & $400.000-600.000$ & $500,000.00$ \\
\hline \multirow[t]{2}{*}{ Overhead (Lain-lain) } & 150.000 & $150,000.00$ \\
\hline & & $650,000.00$ \\
\hline Pemasukan (/hari) & Perkiraan & Rujukan \\
\hline Siang - Sore & $200.000-400.000$ & $300,000.00$ \\
\hline Sore - Malam & $500.000-800.000$ & $700,000.00$ \\
\hline \multirow[t]{2}{*}{ Tengah Malam - Subuh } & $150.000-300.000$ & $250,000.00$ \\
\hline & & $1,250,000.00$ \\
\hline
\end{tabular}

\section{Pembahasan}

\section{Payback Period (PP)}

Payback Period merupakan jangka waktu tertentu yang menunjukkan terjadinya arus penerimaan (cash inflows) secara kumulatif sama dengan jumlah investasi dalam bentuk present value. Perhitungan periode dalam metode ini ditentukan secara bulanan sehingga data yang digunakan terlebih dahulu dijadikan data bulanan. Berdasarkan unsur perhitungan, maka terlebih dahulu yang dilakukan adalah menghitung total pemasukan dan total biaya.

\begin{tabular}{|l|r|}
\hline \multicolumn{2}{|c|}{ Tabel 2. Pemasukan dan Biaya } \\
\begin{tabular}{|l|r|}
\hline \multicolumn{1}{|c|}{ Total Pemasukan } & $9,000,000.00$ \\
\hline Pagi - Sore & $21,000,000.00$ \\
\hline Sore - Malam & $7,500,000.00$ \\
\hline Tengah Malam - Subuh & $37,500,000.00$ \\
\hline \multicolumn{1}{|c|}{ Total Biaya } & $1,250,000.00$ \\
\hline Sewa Tempat & $354,200.00$ \\
\hline Depresiasi : & \\
\hline • Kursi dan Meja 8.500.000/24 & \\
\hline
\end{tabular}
\end{tabular}

\begin{tabular}{|l|r|}
\hline • Peralatan Masak 5.000.000/24 & $208,333.00$ \\
\hline • Peralatan Makan 3.000.000/12 & $250,000.00$ \\
\hline Gaji Karyawan (3 org) & $8,320,000.00$ \\
\hline Listrik dan Air & $700,000.00$ \\
\hline Cup, Plastik, dan sejenisnya & $500,000.00$ \\
\hline Saus, Kecap, Gula, dan lain-lain & $400,000.00$ \\
\hline Bahan Pokok & $15,000,000.00$ \\
\hline Overhead (Lain-lain) & $4,500,000.00$ \\
\hline & $31,482,533.00$ \\
\hline
\end{tabular}

Dengan demikian, pemasukan bersih (kas bersih) :

37,500,000.00 - 31,482,533.00 =6,017,467.00.

Sehingga diperoleh Payback Period sebagai berikut :

$$
37,000,000.00
$$

Payback Period = ------------- $\mathrm{x} 12$ bulan

$$
6,017,467.00
$$

Maka, diketahui Payback Period $=6,149$ bulan.

Selanjutnya informan menyatakan bahwa Payback Period pada daerah penelitian berkisar antara 9 sampai 24 bulan. Dengan demikian, berdasarkan rujukan tersebut di atas maka investasi ini dinyatakan LAYAK DITERIMA.

\section{Net Present Value (NPV)}

Dalam penelitian ini, jangka waktu investasi dihitung berdasarkan rata-rata umur berdirinya café, di mana menurut informan yaitu antara 6 sampai 11 tahun. Dengan menggunakan subyektifitas, peneliti memilih umur investasi sebesar 8 tahun. Tingkat suku bunga diperoleh dengan mencari rata-rata tingkat suku bunga simpanan selama lima tahun terakhir dengan perubahan tidak lebih dari dua persen. Data rata-rata suku bunga simpanan tertinggi menunjukkan berada di angka $6,50 \%$ per tahun. Sementara itu untuk menyesuaikan nilai arus kas didasarkan pada prediksi rata-rata inflasi selama delapan tahun ke depan.

Dikutip dari buku berjudul : "Profil Kota Tangerang Selatan 2018”, yang diterbitkan oleh Badan Perencanaan Pembangunan Daerah (BAPPEDA) Kota Tangerang Selatan Tahun 2018, Laju Pertumbuhan Ekonomi (LPE) di Kota Tangerang Selatan dari tahun 2015 yang lalu 
berkisar antara 6-7,5\% tiap tahunnya. Bahkan dua tahun sebelumnya yaitu 2013 dan 2014 LPE-nya hampir mencapai angka 9\%. Apabila diasumsikan pertumbuhan ekonomi diatas $7,5 \%$ per tahun, maka dapat diperkirakan daya beli masyarakat di Tangerang Selatan cukup tinggi.

Seiring dengan pesatnya pertumbuhan ekonomi di Tangerang Selatan, yang berdampak pula pada tingginya perkembangan industri kuliner pada daerah yang terletak di Selatan Jakarta ini. Hal ini membuat bisnis café juga ikut berkembang sehingga tak heran di mana-mana banyak bermunculan warung/kios-kios atau restoran yang khusus melayani para penikmat kopi di wilayah ini. Dengan asumsi tersebut di atas, maka diperkirakan tingkat daya beli masyarakat di Tangerang Selatan juga cukup tinggi yaitu kira-kira berada pada sekitar 7,5\% per tahun.

\begin{tabular}{|c|c|}
\hline \multicolumn{2}{|c|}{ Tabel 3. Arus Kas Penyesuaian } \\
\hline Periode & Arus Kas \\
\hline 1 & $6,017,467.00$ \\
\hline 2 & $6,468,777.02$ \\
\hline 3 & $6,953,935.30$ \\
\hline 4 & $7,475,480.45$ \\
\hline 5 & $8,036,141.48$ \\
\hline 6 & $8,638,852.09$ \\
\hline 7 & $9,286,766.00$ \\
\hline 8 & $9,983,273.45$ \\
\hline
\end{tabular}

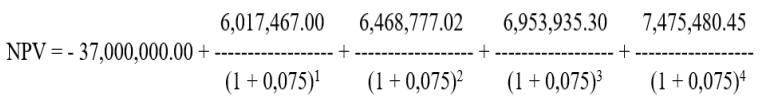

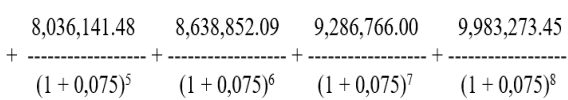

$\mathrm{NPV}=-37,000,000.00+44,792,518.52$

$\mathrm{NPV}=7,792,518.52$

Apabila melihat hasil dari nilai NPV yang menunjukkan hasil positif, maka investasi ini dinyatakan LAYAK DITERIMA.

\section{Internal Rate of Return (IRR)}

Adapun perhitungan IRR yaitu dengan cara interpolasi, yaitu dengan mencari dua nilai NPV. Cara yang dilakukan adalah dengan mensimulasikan nilai discount factor yang menghasilkan nilai NPV positif dan negatif.

\begin{tabular}{|c|c|c|c|}
\hline \multicolumn{4}{|c|}{ Tabel 4. Interpolasi NPV } \\
\hline \multirow{2}{*}{ Periode } & \multirow{2}{*}{ Arus Kas } & $\mathrm{i}_{1}=0,12$ & $\mathrm{i}_{2}=0,13$ \\
\hline & & $\mathrm{NPV}_{1}$ & $\mathrm{NPV}_{2}$ \\
\hline 1 & $6,017,467.00$ & $5,372,738.39$ & $5,325,192.04$ \\
\hline 2 & $6,468,777.02$ & $5,156,869,44$ & $5,066,001.27$ \\
\hline 3 & $6,953,935.30$ & $4,949,772.44$ & $4,819,750.00$ \\
\hline 4 & $7,475,480.45$ & $4,750,861.42$ & $4,585,059.16$ \\
\hline 5 & $8,036,141.48$ & $4,560,030.35$ & $4,361,778.92$ \\
\hline 6 & $8,638,852.09$ & $4,376,761.62$ & $4,149,503.86$ \\
\hline 7 & $9,286,766.00$ & $4,192,873.43$ & $3,947,447.93$ \\
\hline \multirow[t]{2}{*}{8} & $9,983,273.45$ & $4,032,179.59$ & $3,755,369.19$ \\
\hline & & $37,392,086.68$ & $36,010,102,37$ \\
\hline \multirow[t]{2}{*}{ Initial Cost } & $37,000.000 .00$ & & \\
\hline & NPV & $392,086.68$ & $-989,897,63$ \\
\hline $\mathrm{IRR}=i_{1}+$ & $\begin{array}{l}N P V_{1} \\
V_{1}-N P V_{2}\end{array}$ & & \\
\hline $\mathrm{IRR}=0,12$ & $\begin{array}{r}392 \\
086.68-\end{array}$ & 68 & $13-0,12)$ \\
\hline
\end{tabular}

\section{IRR $=12,284 \%$}

Nilai IRR tersebut di atas sesungguhnya dapat dimaknai bahwa dengan rangkaian arus kas yang diterima selama delapan tahun. Tergambar bahwa investasi tersebut di atas memberikan tingkat return sebesar 12,284\%. Dengan nilai return berlaku di pasar (discount factor) saat ini yaitu sebesar 6,50\%, maka dapat dikatakan bahwa investasi ini memberikan keuntungan yang lebih besar apabila dibandingkan dengan investasi lain yang ada dan tersedia di pasar atau di masyarakat. Dengan demikian dapat dikatakan atau disimpulkan bahwa investasi ini LAYAK DITERIMA.

\section{SIMPULAN}

Tangerang Selatan merupakan salah satu kota yang pertumbuhan ekonominya sangat pesat. Sebagai dampak dari perkembangan ekonomi tersebut, geliat untuk berinvestasi juga sangat tinggi. Hal itu salah satunya ditandai dengan banyaknya berdiri usaha-usaha kuliner seperti halnya café. Di berbagai sudut kota, di pinggir-pinggir jalan protokol maupun jalan biasa, hingga gang-gang dan komplek-komplek perumahan tampak berdiri usaha-usaha café, baik yang berskala besar 
maupun yang berskala kecil.

Investor pun banyak sekali yang berminat menanamkan modalnya untuk berbisnis café di Tangerang Selatan. Fenomena ini membuat penulis tertarik untuk melakukan penelitian terhadap banyaknya café-café yang berdiri di Tangerang Selatan. Namun penelitian yang dilakukan lebih fokus pada aspek kriteria penilaian investasi, khususnya yang menyangkut keuangan/finansial.

Berdasarkan hasil dan pembahasan yang dilakukan dalam penelitian terhadap salah satu objek yang diteliti, dapat disimpulkan bahwa investasi yang ditanamkan oleh investor layak dilanjutkan dan dapat diterima. Hal ini sebagaimana tergambar dalam perhitungan Payback Period (PP), Net Present Value (NPV), dan Internal Rate of Return (IRR). Perhitungan dengan menggunakan ketiga metode tersebut menunjukkan hasil yang sesuai dengan asumsi dan perkiraan yang ditetapkan.

Dari hasil penelitian menunjukkan bahwa PP berada pada 6,149 bulan, atau lebih cepat dari PP yang ada di daerah penelitian yaitu berkisar antara 9 sampai 24 bulan. Sementara itu NPV sebesar Rp7,792,518.52 di mana hasil dari nilai NPV ini menunjukkan hasil yang positif. Sedangkan IRR sebesar $12,284 \%$, lebih tinggi dari nilai return yang berlaku di pasar (discount factor) saat ini yaitu sekitar 6,50\%.

Adapun hasil yang diperoleh adalah sebagaimana tampak pada tabel di bawah ini :

\begin{tabular}{|l|c|c|c|}
\hline \multicolumn{4}{c}{ Tabel 5 Kriteria Kelayakan Investasi } \\
\hline Kriteria Investasi & $\begin{array}{c}\text { Indikator } \\
\text { Kelayakan }\end{array}$ & Hasil Perhitungan & Hasil Kelayakan \\
\hline $\begin{array}{l}\text { Payback Period } \\
\text { (12 bulan) }\end{array}$ & $<9-24$ bulan & 6,149 bulan & LAYAK \\
\hline $\begin{array}{l}\text { Net Present Value } \\
\text { (NPV) }\end{array}$ & $>0$ & Rp. 7,792,518.52 & LAYAK \\
\hline $\begin{array}{l}\text { Internal Rate of } \\
\text { Return (IRR) }\end{array}$ & $>6,50 \%$ & $12,284 \%$ & LAYAK \\
\hline
\end{tabular}

\section{DAFTAR PUSTAKA}

Abdullah, F. (2015). Analisis kelayakan investasi aktiva tetap pembelian mesin printing pada PT Radja Digital Printing Samarinda. Jurnal Ilmu Administrasi Bisnis, 3(2), 297-310.

Busthomy, A. F., Saifi, M., \& Zahroh, Z. A. (2016). Analisis kelayakan investasi aktiva tetap
(Studi Pada PT Pion Berkah Sejahtera). Jurnal Administrasi Bisnis, 35(1), 28-34.

Durri, A., Saifi, M., \& Azizah, D. F. (2016). Analisis kelayakan usaha dalam rangka rencana pengembangan usaha (Studi Kasus Pada PO. Zena Pariwisata Malang). Jurnal Administrasi Bisnis, 35(2), 174-180.

Fisu, A. A. (2019). Analisis kelayakan ekonomi \& finansial pada masterplan kawasan industri perikanan Kota Tarakan.

Haming, Murdifin., \& Salim Basalamah (2010). Studi Kelayakan Investasi Proyek dan Bisnis. Jakarta: Bumi Aksara.

Harliana, E. W., Chumaidiyah, E., \& Kamil, A. A. (2019). Analisis kelayakan bisnis startup cuci mobil dan motor di Kota Tangerang Selatan. Jurnal Mitra Manajemen, 3(8), 845-858.

Jumingan. (2011). Studi Kelayakan Bisnis. Jakarta: Bumi Aksara.

Kasmir \& Jakfar. (2017). Studi Kelayakan Bisnis Edisi Revisi. Jakarta: Prenada Media Group.

Kristian, W., \& Indrawan, F. (2019). Studi kelayakan bisnis dalam rangka pendirian XX Cafe. Jurnal Akuntansi, 11(2), 379-400.

Kurniawan, A. (2018). Analisis kelayakan usaha tahu Gemilang di "Karawang". Jurnal Valtech, 1(1), 193-199.

Permadi, I. G. A. D. E. (2020). Analisis investasi penambahan aktiva tetap (mesin oven) pada UD. Warna Sari di Desa Suranadi, Kecamatan Narmada, Kabupaten Lombok Barat. GANEC SWARA, 14(1), 413-418.

Pratiwi, P. W., Rapini, T., \& Farida, U. (2020). Analisis kelayakan pendirian usaha roti canai di Jalan Baru Ponorogo. ISOQUANT: Jurnal Ekonomi, Manajemen dan Akuntansi, 4(1), 120-129.

Purnomo, R. A., Riawan, \& La Ode Sugianto. (2017). Studi Kelayakan Bisnis. Ponorogo: Unmuh Ponorogo Press.

Purwana, Dedi, E. S., \& Nurdin Hidayat. (2017). Studi Kelayakan Bisnis. Depok: PT. RajaGrafindo Persada.

Putri, N. A., Saidah, Z., Supyandi, D., \& Trimo, L. (2020). Analisis kelayakan bisnis kedai kopi (Studi Kasus Pada Agrowisata N8 Malabar, Pangalengan, Kabupaten Bandung). Journal 
of Food System \& Agribusiness, 3(2), 89-100.

Riyanto, Bambang. (2011). Dasar-dasar

Pembelanjaan Perusahaan Edisi 4.

Yogyakarta: BPFE Yogyakarta.

Sartono, Agus R. (2010). Manajemen Keuangan

Teori dan Aplikasi, Edisi Keempat. Yogyakarta:

BPFE Yogyakarta.

Sidiq, I., \& Mauluddin, Y. (2015). Penentuan skala usaha yang ekonomis untuk penggunaan mesin roaster coffee $\mathrm{Tj}$ 068. Jurnal Kalibrasi, 13(1).

Sucipto, A. (2011). Studi Kelaykaan Bisnis Analisis Integratif dan Studi Kasus. Malang: UIN-Maliki Press.

Sugiyono. (2012). Metode Penelitian Kuantitatif, Kualitatif dan R\&D. Bandung: Penerbit Alfabeta.

Suliyanto. (2010). Studi Kelayakan Bisnis Pendekatan Praktis. Purwokerto: Andi Yogyakarta.

Sunyoto, Danang. (2014). Studi Kelayakan Bisnis, Edisi Pertama. Yogyakarta: CAPS (Center Of Academic Publishing Service).

Susanti, R., Nisa, D. C., Khurriyah, H. A., Bahtiar,
E. N., \& Rahardjo, K. A. (2019). C. Analisis studi kelayakan usaha di Resto "I Am Queen". Inovasi Manajemen dan Kebijakan Publik, 2(2), 32-32.

Tandelilin, Eduardus. (2010). Analisis Investasi dan Manajemen Portofolio. Yogyakarta: BPFE Yogyakarta.

Trimintarsih, T. (2019). Analisis kelayakan investasi di usaha jasa transportasi truk (Studi Kasus Pada CV Bangkit Malang). Revitalisasi, 5(4), 71-80.

Umar, H. (2015). Studi Kelayakan Bisnis Edisi Revisi 3. Jakarta: PT. Gramedia Pustaka Utama.

Utari, N., Chumaidiyah, E., \& Kamil, A. A. (2019). Analisis kelayakan pengembangan bisnis start up my fresh laundry di Kota Solok secara online dan offline. eProceedings of Engineering, 6(2).

Weston, J. F., \& Copeland, T. E. (2010). Manajemen Keuangan. Tangerang: Binarupa Aksara.

Wijayanto, Dian. (2012). Pengantar Manajemen. Jakarta: PT. Gramedia Pustaka Utama. 